\title{
PENGARUH SUBSTITUSI CANGKANG TIRAM SEBAGAI PENGGANTI SEBAHAGIAN SEMEN DAN PASIR HALUS TERHADAP KUAT TARIK BELAH BETON
}

\author{
Bunyamin $^{1)}$, Nesri Hendrifa ${ }^{2)}$, Muhammad Ridha ${ }^{3)}$ \\ ${ }^{1)}$ Universitas Iskandar Muda, Jalan Kampus Unida No. 15 Surien, Banda Aceh \\ ${ }^{2)}$ Universitas Syiah Kuala, Jl. T. Nyak Arief, No. 441, Darussalam, Banda Aceh \\ ${ }^{3)}$ Universitas Abulyatama, Jl. Blang Bintang Lama Km. 8,5 Lampoh Keude, Aceh Besar \\ Email: bunyamin@unida-aceh.ac.id ${ }^{1)}$,hendrifa1983@gmail.com ${ }^{2}$, \\ ridha_sipil@abulyatama.ac.id ${ }^{3)}$
}

DOI: http://dx.doi.org/10.29103/tj.v11i2.486

(Received: February 2021 / Revised: March 2021 / Accepted: May 2021)

\begin{abstract}
Abstrak
Pembangunan di bidang struktur saat ini mengalami kemajuan yang demikian pesat. Oleh karena itu perlunya alternatif untuk mengatasi keterbatasan material penyusun yang diambil dari alam yaitu salah satunya menggunakan limbah cangkang tiram sebagai bahan pengganti sebagian semen dan agregat halus. Hal ini cukup beralasan karena bahan penyusun semen portland adalah $60 \%$ sampai $70 \%$ terdiri atas kapur atau $\mathrm{CaO}$, dan $17 \%$ sampai $25 \%$ terdiri dari $\mathrm{SiO} 2$ (SNI-15-2049-2004), penggunaan cangkang tiram yang mengandung unsur $\mathrm{CaO}$ sebesar 53,03\% dan $\mathrm{SiO} 2$ sebesar $0,82 \%$ sebagai bahan perekat. Tujuan penelitian yaitu untuk mengetahui "Pengaruh perbandingan komposisi campuran abu dan serbuk cangkang tiram terhadap kuat tarik belah beton dengan substitusi semen dan pasir halus sebesar 0\%, 5\%, 10\% dan 15\% untuk umur beton 28 hari dengan faktor air semen $0,40,0,50$ dan 0,60 , dengan jumlah benda uji 60 buah. Penelitian dilakukan di laboratorium dengan berdasarkan pada ACI (American Concrete Institute), ASTM (American Society for Testing \& Materials) dan SNI (Standar Nasional Indonesia). Berdasarkan hasil penelitian diperoleh bahwa kuat tarik belah beton tertinggi pada FAS 0,50 dengan pencampuran cangkang tiram 5\% yaitu sebesar 4,02 MPa. Sedangkan beton normal, kuat tarik beton tertinggi diperoleh pada FAS 0,40 yaitu sebesar 3,72 MPa.
\end{abstract}

Kata kunci: cangkang tiram, abu, FAS, kuat tarik belah beton.

\begin{abstract}
The construction has increased very rapidly. So that it requires an alternative to find a substitute for other materials that can be used in forming a concrete, one of which is using oyster shell waste as a partial substitute for cement and fine aggregate. In general, the compotition of Portland Cement are $60 \%$ to $70 \%$ consisting of lime or $\mathrm{CaO}$, and $17 \%$ to $25 \%$ consisting of $\mathrm{SiO} 2$ (SNI-15-2049-2004), the use of oyster shells containing $\mathrm{CaO}$ elements is $53.03 \%$ and $\mathrm{SiO} 2$ of $0.82 \%$ as an adhesive. The research objective was to determine the effect of oyster shell as a substitute of cement and fine sand due to the tensile strength of concrete. The substitution of cement and fine sand was $0 \%, 5 \%, 10 \%$ and $15 \%$ for 28 days of concrete with a water cement ratio of $0,40,0,50$ and 0,60 The sylindrical concrete used in this research was 60 specimens. The research was carried out in the laboratory based on ACI (American Concrete Institute), ASTM (American Society for Testing \& Materials) and SNI (Indonesian National Standard). Based on the results, it was found that the highest
\end{abstract}

Pengaruh Substitusi Cangkang Tiram Sebagai Pengganti Sebahagian Semen Dan Pasir Halus Terhadap Kuat Tarik Belah Beton - Bunyamin, Nesri Hendrifa, Muhammad Ridha 
tensile strength of concrete was obtained at water cemen ratio of 0,50 by mixing $5 \%$ oyster shells, namely 4.02 MPa. While for normal concrete, the highest tensile strength of concrete is obtained at water cement ratio of 0,40 which is $3.72 \mathrm{MPa}$.

Keywords: oyster shell, ash, water cement ratio, tensile strength of concrete.

\section{Latar Belakang}

Saat ini berbagai cara serta penelitian dilakukan dan terus dikembangkan dengan tujuan meningkatkan kekuatan tarik belah beton, salah satunya pada material pembentuk beton itu sendiri. Hal ini dilakukan dengan cara mensubstitusikan bahan-bahan pengganti, baik agregat kasar, agregat halus, semen dan juga bahan tambah untuk meningkatkan daya rekat dari bahan pengikat dalam beton. Bahan tersebut difokuskan dengan memanfaatkan material limbah.

Dalam penelitian ini digunakan cangkang tiram yang berasal dari Krueng Neng, Aceh Besar sebagai bahan tambah dalam pembuatan beton. Kandungan protein di dalam tiram merupakan jenis makanan yang bersumber dari laut yang cukup berlimpah, tentunya jumlah cangkangnya juga akan sebanding. Selama ini cangkang tiram yang tidak digunakan lagi oleh para nelayan, dibuang dan dibiarkan begitu saja, sehingga menyebabkan pencemaran lingkungan.

Penggunaan serbuk cangkang tiram sebagai bahan campuran beton telah banyak digunakan. Hal ini disebabkan oleh adanya kandungan $\mathrm{CaO}$ yang cukup tinggi. Abu cangkang tiram mengandung senyawa kimia yang bersifat pozzolan, yaitu mengandung zat kapur $(\mathrm{CaO})$, alumina dan senyawa silika sehingga berpotensi untuk digunakan sebagai bahan baku beton alternatif (Li, Song, and Hong, 2007). Limbah cangkang tiram dapat digunakan sebagai pengganti sebahagian semen di dalam beton, karena sifatnya yang mirip dengan zat kapur, namun pencampuran limbah cangkang tiram terhadap semen sampai dengan $25 \%$ akan menurunkan mutu beton (Ubachukwu and Okafor, 2019).

Cangkang tiram merupakan bahan limbah yang dapat mencemarkan lingkungan dan digunakan sebagai pengganti agregat kasar sebesar 50\% menunjukkan bahwa berat beton dalam $1 \mathrm{~m}^{3}$ adalah $1993 \mathrm{Kg} / \mathrm{m}^{3}$ dan tergolong ke dalam beton ringan. Daya serap air untuk cangkang tiram yang digantikan sebesar $50 \%$ dari agregat halus terhadap beton berongga masih dalam batas yang diijinkan (Eo and Yi, 2015).

Tabel 1 Sifat kimia serbuk cangkang tiram

\begin{tabular}{ccc}
\hline No. & Sifat kimia & Jumlah \\
\hline 1 & $\mathrm{SiO}_{2}$ & 1,60 \\
\hline 2 & $\mathrm{AL}_{2} \mathrm{O}_{3}$ & 0,92 \\
\hline 3 & $\mathrm{CaO}$ & 51,56 \\
\hline 4 & $\mathrm{MgO}$ & 1,43 \\
\hline 5 & $\mathrm{Na}_{2} \mathrm{O}$ & 0,08 \\
\hline 6 & $\mathrm{~K}_{2} \mathrm{O}$ & 0,06 \\
\hline 7 & $\mathrm{H}_{2} \mathrm{O}$ & 0,31 \\
\hline 8 & $\mathrm{LO}$ & 41,84 \\
\hline
\end{tabular}

Abu kulit kerang diaplikasikan sebagai pengganti semen dalam campuran mortar dan memperbaiki kemampuan kerja pada pasangan bata dan plesteran 
mortar (Lertwattanaruk, Makul, and Siripattarapravat, 2012). Potensi cangkang tiram sebagai pengganti semen sangat besar dikarenakan di dalam 100 gram cangkang tiram mengandung 52 gram $\mathrm{CaO}$ dan mengandung 48 gram zat-zat kimia lainnya (Ayyappan, 2018). Untuk lebih jelasnya, dapat dilihat pada Tabel 1.

Pada zaman kuno China dan Taiwan selama ratusan tahun lalu telah digunakan abu tiram sebagai pengganti semen dalam membuat suatu bangunan kuil. Penelitian tentang abu tiram sebagai pengganti semen menunjukkan rasio atau perbandingan antara kuat belah tarik dan kuat tekan yang sangat signifikan jika dibandingkan dengan beton konvensional. Hasil penelitian menunjukkan kuat belah tarik untuk beton yang menggunakan abu cangkang tiram sebagai pengganti semen adalah sebesar 16,1\% - 19,9\% dari nilai kuat tekan beton. Sedangkan beton konvensional menunjukkan nilai kuat belah tarik sebesar $10 \%-14 \%$ dari kuat tekan beton (Chang et al, 2019).

$\mathrm{Abu}$ kerang laut yang digunakan sebagai pengganti sebahagian semen sebesar $15 \%$ dapat meningkatkan mutu beton. Beton dengan abu kerang laut sebagai pengganti sebahagian semen menghasilkan mutu beton yang berkualitas yaitu dalam hal komposisi kimia, berat jenis, kuat tekan, kuat lentur, dan kuat tarik. Cangkang kerang laut merupakan limbah dari laut yang dapat dimanfaatkan secara optimal untuk mengatasi masalah pencemaran lingkungan yaitu dengan memanfaatkanya sebagai pengganti semen dalam beton (Mohammad et al, 2017).

Penggunaan bahan limbah yang memiliki potensi kandungan $\mathrm{CaO}$ sebagai pengganti sebahagian semen dalam beton akan berpengaruh kepada kekuatan beton, daya tahan terhadap suhu panas atau dingin, daya tahan terhadap korosi serta setting time waktu awal dan waktu akhir pengikatan pasta (De Belie, Soutsos, and Gruyaert, 2018).

Adapun tujuan dari penelitian ini adalah untuk memanfaatkan limbah cangkang kerrang dari Krueng Neng, Aceh Besar sebagai pengganti sebahagian agregat halus disubstitusikan ke dalam semen dan untuk mengetahui seberapa besar kuat tarik belah beton terhadap penambahan abu dan serbuk cangkang tiram Krueng Neng ke dalam beton.

\section{Metode Penelitian}

Penelitian dilaksanakan di Laboratorium Bahan Bangunan dan Transportasi Prodi Teknik Sipil, Fakultas Teknik, Universitas Iskandar Muda yang berdasarkan kepada pedoman ASTM (American Society for Testing of Materials) dan ACI (American Concrete Institute). Agregat yang digunakan berasal dari Jantho, Kabupaten Aceh Besar, Provinsi Aceh.

Penelitian dimulai dengan mengumpulkan cangkang tiram dalam jumlah yang banyak sekitar $200 \mathrm{Kg}$ melalui para nelayan yang berada di Krueng Neng, Aceh Besar. Adapun jenis cangkang tiram yang digunakan adalah jenis Crassostrea Gigas (Octavina, Yulianda, and Krisanti, 2014). Cangkang tiram tersebut dihaluskan dengan menggunakan mesin Los Angeles Test kemudian dihaluskan lagi dengan ditumbuk secara manual dengan menggunakan lesung. Cangkang tiram yang sudah menjadi serbuk diayak dengan menggunakan saringan Standar ASTM yaitu berdiameter $2,36 \mathrm{~mm}$. Serbuk cangkang tiram tersebut digunakan sebagai pengganti sebahagian dari agregat halus, kemudian sebahagian cangkang tiram lainnya dibakar dengan menggunakan drum bekas. Drum bekas terdiri dari 2 (dua) lapisan yaitu lapisan atas tempat diletakkannya cangkang tiram, sedangkan lapisan 
bawah adalah tempat diletakkannya bahan bakar berupa kayu bekas. Setiap pembakaran cangkang tiram dalam drum tersebut membutuhkan waktu sekitar 2 jam. Cangkang tiram yang sudah rapuh diangkat dan ditumbuk halus menjadi abu dengan menggunakan lesung. Abu cangkang tiram diayak dengan saringan standar ASTM nomor 200. Abu cangkang tiram disubstitusikan sebagai pengganti sebahagian semen.

Perhitungan rancangan campuran beton dalam satuan kilogram, yang mana jumlah air yang dibutuhkan untuk $1 \mathrm{~m}^{3}$ beton didasarkan pada tinggi slump rencana dan diameter maksimum agregat yang direncanakan (ACI 2005). Pada penelitian ini slump yang digunakan adalah 75-100 mm dengan diameter agregat maksimum 25,4 mm serta Faktor Air Semen (FAS) adalah 0,4, 0,5, dan 0,6. Jumlah air yang didapatkan pada masing masing FAS adalah sama yaitu $186,76 \mathrm{Kg} / \mathrm{m}^{3}$. Sedangkan jumlah semen yang didapatkan setiap FAS adalah berbeda, di mana semakin besar nilai FAS maka semakin kecil jumlah semen yang diperlukan dalam $1 \mathrm{~m}^{3}$. Jumlah agregat kasar didapatkan berdasarkan berat volume dan koefesien agregat kasar (ACI, 2005). Berat beton sebesar 2395,60 Kg/m³ didapatkan berdasarkan diameter agregat 25,4 $\mathrm{mm}$ (ACI, 2005). Berat agregat halus didapatkan dengan mengurangkan berat beton. Hasil perencanaan campuran beton dapat dilihat pada Tabel 2.

Tabel 2 Hasil perencanaan campuran beton

\begin{tabular}{clrrr}
\hline \multirow{2}{*}{ No. } & Campuran untuk $1 \mathrm{~m}^{3}$ & \multicolumn{3}{c}{ Berat material $(\mathrm{kg})$} \\
\cline { 3 - 5 } & beton & FAS 0,40 & FAS 0,50 & FAS 0,60 \\
\hline 1 & Air & 186,76 & 186,76 & 186,76 \\
\hline 2 & Semen & 1274,43 & 373,52 & 311,27 \\
\hline 3 & Kerikil & 253,76 & 304,44 & 338,23 \\
\hline 4 & Pasir Kasar & 213,75 & 256,45 & 284,91 \\
\hline 5 & Pasir Halus & 2395,60 & 2395,60 & 2395,60 \\
\hline & Jumlah & & &
\end{tabular}

Penambahan serbuk dan abu limbah anorganik ke dalam semen dan agregat halus dibagi ke dalam 3 variasi yaitu variasi 1 sebesar 5\%, variasi 2 sebesar $10 \%$, dan variasi 3 sebesar $15 \%$ (Bunyamin et al, 2021). Variasi 1 penambahan cangkang tiram sebesar 5\% yaitu abu cangkang tiram disubstitusikan ke dalam semen sebesar $5 \%$ dan serbuk cangkang tiram sebagai filler ke dalam pasir halus sebesar $5 \%$. Variasi 2 penambahan cangkang tiram sebesar $10 \%$ yaitu abu cangkang tiram ke dalam semen sebesar $10 \%$ dan serbuk cangkang tiram ke dalam pasir halus sebesar $10 \%$. Variasi 3 penambahan cangkang tiram sebesar $15 \%$ yaitu abu cangkang tiram ke dalam semen sebesar $15 \%$ dan serbuk cangkang tiram ke dalam pasir halus sebesar $15 \%$. Semen yang digunakan adalah semen tipe 1, agregat halus yang digunakan adalah yang lolos saringan ukuran 4,76 mm untuk pasir halus dan 9,52 mm untuk pasir kasar (Bunyamin, 2019). Jumlah benda uji untuk masing-masing penambahan serbuk dan abu cangkang tiram adalah sebanyak 5 (lima) buah. Total benda uji di dalam penelitian ini adalah 60 (enam puluh) buah.

Adapun tahap pelaksanaan pembuatan beton dengan menggunakan bahan tambah cangkang tiram sebagai pengganti semen dan pasir halus adalah sebagai berikut: 
1. Persiapan material dan alat-alat yang digunakan untuk pembuatan benda uji.

2. Pemeriksaan sifat fisis terhadap material dilakukan di laboratorium yang meliputi pemeriksaan susunan butiran agregat, pemeriksaan berat volume agregat, dan pemeriksaan berat jenis agregat.

3. Perencanaan campuran beton (mix design). Menimbang material dan bahanbahan sesuai dengan hitungan yang telah ditentukan pada perencanaan campuran beton. Proses pengadukan pada beton dilakukan dengan memasukkan material yang telah siap ditimbang pembentuk beton (benda uji) yaitu agregat kasar, halus, dan pasir, cangkang tiram lolos saringan $200 \mathrm{~mm}$ digunakan sebagai bahan pengganti sebagian semen dan cangkang tiram yang lolos saringan $4,75 \mathrm{~mm}$ digunakan sebagai bahan pengganti Sebagian agregat halus, air, dan semen ke dalam molen (concrete mixer). Pengadukan menggunakan molen dilakukan sampai homogen kemudian tuang adukan ke alas campuran beton selama \pm 15 menit.

4. Pengukuran kekentalan pada beton basah diuji dengan menggunakan alat uji slump. Kekentalan beton basah yang telah diuji slump adalah $75-100 \mathrm{~mm}$.

5. Campuran beton kemudian dituangkan ke dalam cetakan silinder yang sebelumnya sudah dioles dengan oli agar campuran beton tidak melekat pada dinding cetakan. Setelah dituangkan ke dalam cetakan, dipadatkan dengan memukul sisi cetakan menggunakan palu karet dan setelah padat ratakan permukaanya menggunakan sendok semen. Perawatan pada beton dilakukan ketika beton sudah mengeras. Setelah beton mengeras di dalam cetakan, keluarkan beton dari dalam cetakan silinder, kemudian beton direndam didalam air selama 28 hari dengan suhu $2^{0} 0 \mathrm{C} \pm 3^{\circ} \mathrm{C}$ dan dengan angka kelembapan di atas 90\% (Xianglin Gu Xianyu Jin, 2015).

Kuat tarik belah beton dengan benda uji berbentuk silinder adalah nilai kuat tarik belah tidak langsung dari benda uji beton yang diperoleh dari hasil pembebanan benda uji tersebut yang diletakkan mendatar sejajar dengan permukaan meja penekan mesin uji tekan. Secara umum, kekuatan tarik beton relatif rendah yaitu antara 9\% - 15\% dari kekuatan tekan beton. Kekuatan ini lebih sukar untuk diukur dan hasilnya berbeda-beda dari satu bahan percobaan ke bahan percobaan yang lain dibandingkan untuk silinder-silinder tekan (Dipohusodo, 1994). Kuat tarik belah dapat dihitung dengan persamaan:

$$
f r=\frac{2 . P}{\pi \cdot L \cdot D}
$$

di mana:

$$
\begin{aligned}
& \mathrm{fr}=\text { kekuatan tarik belah }\left(\mathrm{N} / \mathrm{mm}^{2}\right) \\
& \mathrm{P}=\text { beban pada waktu belah }(\mathrm{N}) \\
& \mathrm{L}=\text { tinggi benda uji silinder }(\mathrm{mm}) \\
& \mathrm{D}=\text { diameter benda uji silinder }(\mathrm{mm})
\end{aligned}
$$

Dalam penelitian ini, perpaduan antara serbuk dan abu cangkang tiram Krueng Neng dimasukkan ke dalam material pembentuk beton. Cangkang tiram dihaluskan dengan menggunakan mesin Los Angeles Test yang lolos saringan ukuran 2,36 mm digunakan sebagai pengisi agregat halus serta dibakar yang lolos saringan nomor 200 digunakan sebagai pengganti sebahagian semen. Dengan 
adanya penelitian ini diharapkan cangkang tiram Krueng Neng dapat digunakan sebagai pengganti sebahagian semen dan agregat halus serta dapat mengurangi pencemaran lingkungan.

Pengujian kuat tarik belah beton maksimum dilaksanakan pada saat umur beton mencapai 28 (dua puluh delapan) hari dengan menggunakan alat mesin tekan. Sebelum pengujian, benda uji ditimbang beratnya dan diukur dimensinya. Benda uji yang telah disiapkan ditempatkan di antara dua buah plat pembebanan. Benda uji silinder diletakkan secara horizontal pada mesin uji dengan sumbu silinder tegak lurus pembebanan. Pembebanan dilakukan sampai benda uji terbelah menjadi dua. Sebelum beban sesungguhnya diberikan, terlebih dahulu diberikan plat pembebanan pada posisi yang telah ditentukan. Plat kayu dengan lebar $3 \mathrm{~cm}$ dan panjang $40 \mathrm{~cm}$ disiapkan diantara muka atas dan bawah landasan benda uji. Pembacaan beban pada benda uji sampai maksimumnya dilihat pada saat turunnya angka pembebanan yang diikuti dengan benda uji terbelah secara memanjang. Beban yang menyebabkan benda uji sudah terbelah merupakan data yang kemudian digunakan untuk memperoleh data kuat tarik belah beton.

\section{Hasil dan Pembahasan}

Hasil penelitian meliputi susunan butiran untuk agregat campuran, komposisi campuran agregat beton, hasil pemeriksaan mutu adukan beton, dan hasil pengujian kuat tarik belah beton.

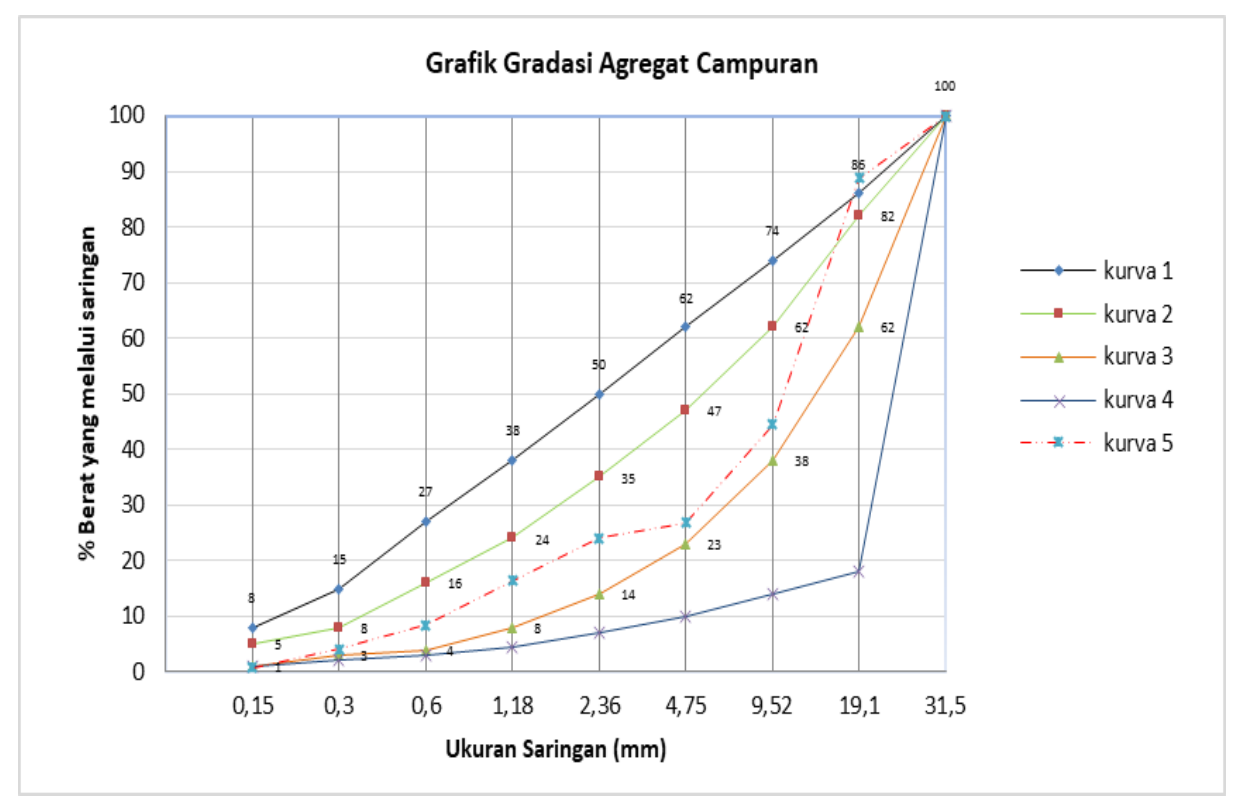

Gambar 1 Daerah susunan butiran untuk agregat campuran

Dari Gambar 1 menunjukkan bahwa kurva 1 sampai dengan kurva 4 merupakan susunan butiran agregat campuran (Nasional, 2019). Kurva 5 adalah hasil pengujian sifat-sifat fisis agregat campuran, yang mempunyai susunan butiran agregat campuran yang berada di daerah baik sekali, dengan demikian agregat yang digunakan tidak terlalu sulit dalam pengadukan, tidak diperlukan banyak semen dan air. 
Pengujian kuat tarik belah beton terhadap 60 (enam puluh) benda uji silinder beton pada umur 28 hari diperlihatkan pada Tabel 3 berikut.

Tabel 3 Hasil pengujian kuat tarik silinder beton

\begin{tabular}{|c|c|c|c|c|}
\hline FAS & $\begin{array}{l}\text { Umur } \\
\text { (Hari) }\end{array}$ & $\begin{array}{c}\text { Kadar abu dan serbuk } \\
\text { cangkang tiram } \\
\%\end{array}$ & $\begin{array}{c}\text { Nama benda } \\
\text { uji }\end{array}$ & $\begin{array}{c}\text { Kuat tarik } \\
\text { beton } \\
(\mathrm{MPa})\end{array}$ \\
\hline \multirow{4}{*}{0,40} & \multirow{4}{*}{28} & 0 & BN-0,40 & 3,72 \\
\hline & & 5 & CT5-0,4 & 3,61 \\
\hline & & 10 & CT10-0,4 & 3,40 \\
\hline & & 15 & CT15-0,4 & 3,16 \\
\hline \multirow{4}{*}{0,50} & \multirow{4}{*}{28} & 0 & CT-0,50 & 3,41 \\
\hline & & 5 & CT5-0,5 & 4,02 \\
\hline & & 10 & CT10-0,5 & 3,36 \\
\hline & & 15 & CT15-0,5 & 3,10 \\
\hline \multirow{4}{*}{0,60} & \multirow{4}{*}{28} & 0 & CT- 0,60 & 3,16 \\
\hline & & 5 & CT5-0,6 & 3,18 \\
\hline & & 10 & CT10-0,6 & 3,30 \\
\hline & & 15 & CT15-0,6 & 3,14 \\
\hline
\end{tabular}

Keterangan
BN
$=$ beton normal
CT5-0,40 = substitusi cangkang tiram sebesar $5 \%$ dan FAS 0,40
CT10-0,40= substitusi cangkang tiram sebesar $10 \%$ dan FAS 0,40
CT15-0,40= substitusi cangkang tiram sebesar $15 \%$ dan FAS 0,40
CT5-0,50 = substitusi cangkang tiram sebesar $5 \%$ dan FAS 0,50
CT10-0,50= substitusi cangkang tiram sebesar $10 \%$ dan FAS 0,50
CT15-0,50= substitusi cangkang tiram sebesar $15 \%$ dan FAS 0,50
CT5-0,60 = substitusi cangkang tiram sebesar $5 \%$ dan FAS 0,60
CT10-0,60 = substitusi cangkang tiram sebesar $10 \%$ dan FAS 0,60
CT15-0,60= substitusi cangkang tiram sebesar $15 \%$ dan FAS 0,60

\subsection{Substitusi Limbah Cangkang Tiram Untuk FAS 0,40}

Penggunaan FAS 0,40 dan substitusi cangkang tiram ke dalam sebahagian semen dan agregat halus mempengaruhi kuat tarik beton seperti pada Gambar 2.

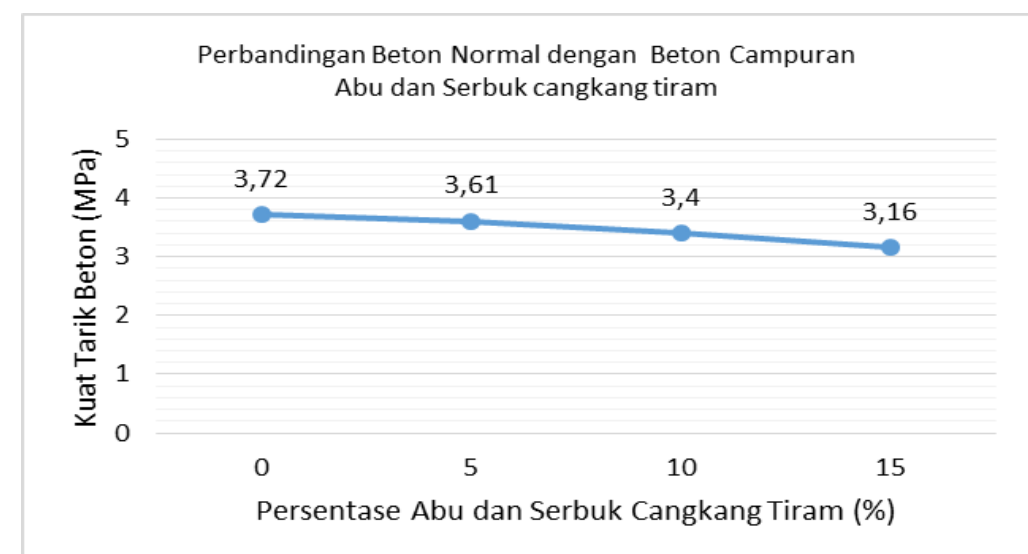

Gambar 2 Substitusi limbah cangkang tiram untuk FAS 0.40

Pengaruh Substitusi Cangkang Tiram Sebagai Pengganti Sebahagian Semen Dan Pasir Halus Terhadap Kuat Tarik Belah Beton - Bunyamin, Nesri Hendrifa, Muhammad Ridha 
Dari Gambar 2 menunjukkan bahwa hasil pengujian kuat tarik beton normal pada umur 28 hari dengan FAS 0,40 yaitu 3,72 MPa. Sedangkan kuat tarik beton dengan penambahan abu dan serbuk cangkang tiram sebesar 5\%, 10\%, dan $15 \%$ mengalami penurunan, yaitu 3,61 $\mathrm{MPa}, 3,40 \mathrm{MPa}$, dan 3,16 $\mathrm{MPa}$. Hal ini dikarenakan adanya penyerapan air yang sangat tinggi oleh limbah cangkang tiram pada saat proses pengadukan beton, sehingga semakin banyak jumlah limbah cangkang tiram di dalam beton, maka semakin kecil kuat tarik beton.

\subsection{Substitusi Limbah Cangkang Tiram Untuk FAS 0,50}

Penggunaan FAS 0,50 dan substitusi cangkang tiram ke dalam sebahagian semen dan agregat halus mempengaruhi kuat tarik beton, yaitu pada Gambar 3 .

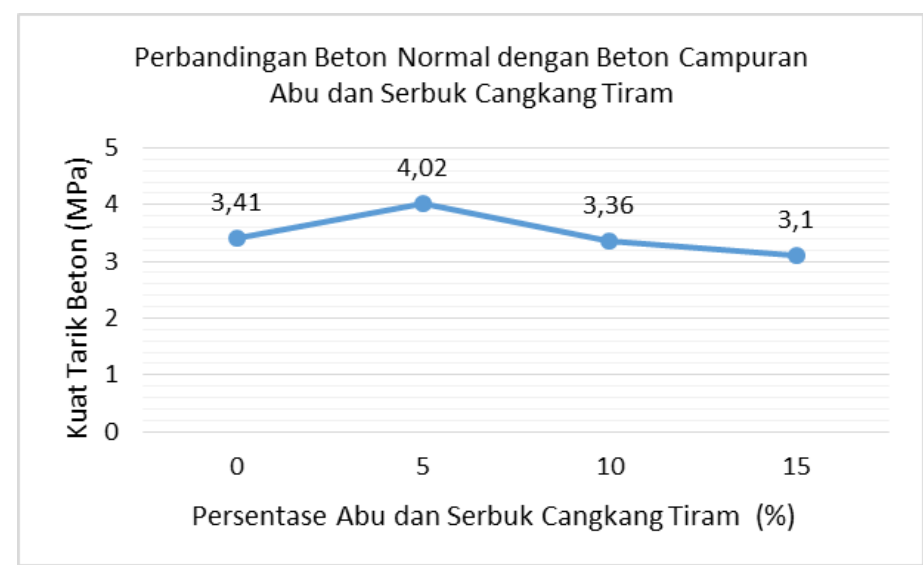

Gambar 3 Substitusi limbah cangkang tiram untuk FAS 0.50

Dari Gambar 3 menunjukkan bahwa nilai kuat tarik beton normal pada FAS 0,50 adalah sebesar 3,41 MPa. Untuk substitusi abu dan serbuk cangkang tiram ke dalam beton $5 \%$, $10 \%$, dan $15 \%$ berturut-turut didapatkan nilai kuat tarik beton yaitu sebesar 4,02 MPa, 3,36 MPa, dan 3,10 MPa. Dengan FAS 0,50, kuat tarik beton dengan penambahan limbah cangkang tiram 5\% lebih besar dibandingkan beton normal. Hal ini dikarenakan jumlah semen pada FAS 0,50 yang lebih sedikit dibandingkan jumlah semen pada FAS 0,40 sehingga semen yang bereaksi dengan air dan limbah cangkang tiram dapat meningkatkan kuat tarik beton, namun, campuran dengan variasi abu dan serbuk cangkang tiram 10\% dan $15 \%$ mengalami penurunan, dikarenakan karena adanya penyerapan air yang sangat tinggi oleh limbah cangkang tiram pada saat proses pengadukan beton.

\subsection{Substitusi Limbah Cangkang Tiram Untuk FAS 0,60}

Penggunaan FAS 0,60 dan substitusi cangkang tiram ke dalam sebahagian semen dan agregat halus mempengaruhi kuat tarik beton seperti diperlihatkan pada Gambar 4 menunjukkan bahwa kuat tarik beton normal diperoleh sebesar 3,16 $\mathrm{MPa}$. Kuat tarik beton tertinggi dengan substitusi limbah cangkang tiram pada pencampuran $10 \%$ yaitu sebesar 3,30 MPa hal ini dikarenakan jumlah semen pada FAS 0,60 yang lebih sedikit jika dibandingkan dengan FAS 0,50, sehingga initial setting time (waktu ikat awal) pasta tidak begitu cepat dan tentunya hal ini membuat kinerja beton semakin mudah serta pemadatan beton mudah dilakukan 
sedangkan pencampuran limbah cangkang tiram sebesar 5\% dan 15\% didapatkan dengan nilai yang tidak jauh beda yaitu sebesar 3,18 MPa dan 3,14 MPa.

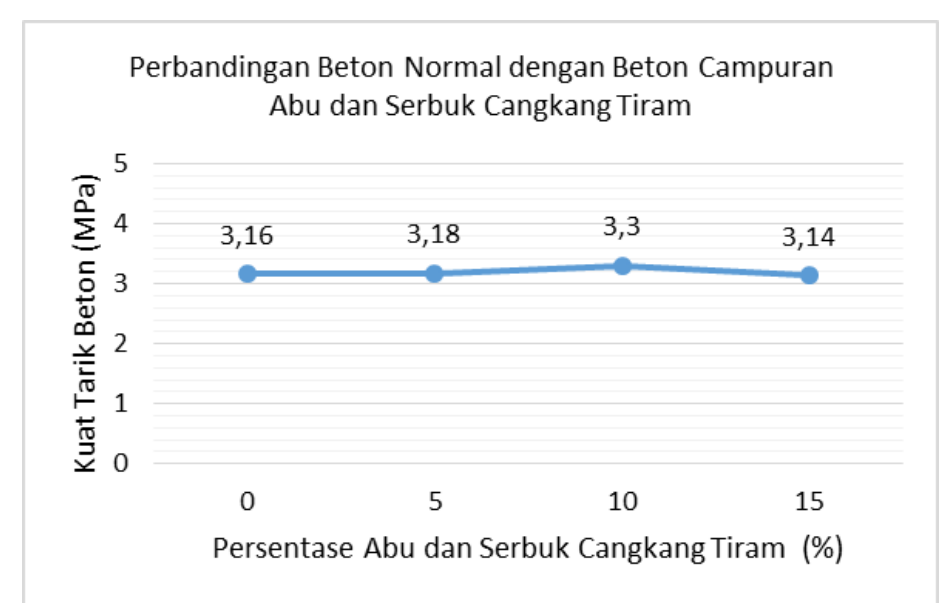

Gambar 4 Substitusi limbah cangkang tiram untuk FAS 0.60

\section{Kesimpulan dan Saran}

\subsection{Kesimpulan}

Penggantian semen dan agregat halus dengan abu dan serbuk cangkang tiram sebesar 5\%, 10\% dan 15\% dengan FAS 0,40, 0,50, dan 0,60 sangat berpengaruh terhadap peningkatan nilai kuat tarik belah beton. Kuat tarik belah beton normal maksimum terjadi pada FAS 0,40 yaitu 3,72 MPa. Sedangkan kuat tarik belah beton dengan substitusi limbah cangkang tiram terbesar terjadi pada subtitusi 5\% dengan FAS 0,5 yaitu sebesar 4,02 MPa. Hal ini dikarenakan jumlah semen pada FAS 0,50 yang lebih sedikit dibandingkan jumlah semen pada FAS 0,40 , sehingga semen yang bereaksi dengan air dan limbah cangkang tiram dapat tercampur secara homogen dan pengerjaan pencampuran mudah (workability) sehingga meningkatkan kuat tarik belah beton.

\subsection{Saran}

Penggunaan limbah cangkang tiram yang disubstitusikan ke dalam beton akan mempengaruhi nilai slump beton, di mana slump yang didapatkan rendah, sehingga akan mempersulit pengerjaan, maka pada waktu pengecoran (pembuatan benda uji), sebaiknya disiapkan air tambahan sebesar $2 \%$ atau $4 \%$ supaya slump tercapai sesuai dengan yang direncanakan.

Dalam penyiapan material abu cangkang tiram, perlu diperhatikan bahwa persentase kehilangan cangkang tiram setelah dibakar adalah sebesar $15 \%$. Sedangkan untuk serbuk cangkang tiram, kehilangan cangkang tiram setelah ditumbuk adalah sebesar 5\% dari jumlah cangkang tiram yang digunakan.

\section{Daftar Kepustakaan}

ACI, 2005. ACI Manual of Concrete Practice 2005, Part I. Report: ACI 104-71 (97) to ACI 223-98 Selecting Proportions For Mass Concrete (ACI 211.191). American Concrete Institute, Detroit, Michigan. 
Ayyappan, K, 2018. Study on Structural Behavior of Oyster Shell Powder in Concrete. Joumal of Engineering and Applied Sciences.

Belie, Nele De, Marios Soutsos, and Elke Gruyaert, 2018. Properties of Fresh and Hardened Concrete Containing Supplementary Cementitious Materials. Springer.

Bunyamin, 2019. Comparison of Deflection of Hollow Block Concrete Blocks with Normal Reinforced Concrete Beam. In AIP Conference Proceedings, 2059:20039.

Bunyamin, B, R P Munirwan, M Ridha, and N Hendrifa, 2021. Utilization of Wood Processing Dust as a Substitute for a Part of Cement in Concrete. In IOP Conference Series: Materials Science and Engineering, 1087:12004.

Chang, Ching-Jong, Ta-Peng Chang, Chun-Tao Chen, and Yu-Wen Liu, 2019. Mix Proportion and Engineering Behavior of San-Ho-Tu Building Material for Temples and Ancestral Clan Houses. In Structural Analysis of Historical Constructions, 1585-93, Springer.

Dipohusodo, Istimawan, 1994. Struktur Beton Bertulang: Berdasarkan SK SNI T15-1991-03 Departemen Pekerjaan Umun RI. Gramedia Pustaka Utama.

Eo, Seok-Hong, and Seong-Tae Yi, 2015. Effect of Oyster Shell as an Aggregate Replacement on the Characteristics of Concrete. Magazine of Concrete Research 67 (15): 833-42.

Lertwattanaruk, Pusit, Natt Makul, and Chalothorn Siripattarapravat, 2012. Utilization of Ground Waste Seashells in Cement Mortars for Masonry and Plastering. Journal of Environmental Management 111 (November): 13341. https://doi.org/10.1016/J.JENVMAN.2012.06.032.

Li, Y, W D Song, and P Z Hong, 2007. Changing Wastes into ValuablesDiscussion on Comprehensive Development and Utilization of Oyster Shell. In Doctor. Expert Forum, 26.

Mohammad, Wan Ahmad Soffian Bin Wan, Nor Hazurina Othman, Mohd Haziman Wan Ibrahim, Masazurah A Rahim, Shahiron Shahidan, and Raha Abd Rahman, 2017. A Review on Seashells Ash as Partial Cement Replacement. In IOP Conference Series: Materials Science and Engineering, 271:12059.

Nasional, Badan Standarisasi, 2019. Persyaratan Beton Struktural Untuk Bangunan Gedung Dan Penjelasan (SNI 2847: 2019). Jakarta.

Octavina, Chitra, Fredinan Yulianda, and Majariana Krisanti, 2014. Struktur Komunitas Tiram Dagingdi Perairan Estuaria Kuala Gigieng, Kabupaten Aceh Besar, Provinsi Aceh. DEPIK Jurnal Ilmu-Ilmu Perairan, Pesisir Dan Perikanan 3 (2).

Ubachukwu, Obiekwe A, and Fidelis O Okafor, 2019. Investigation of the Supplementary Cementitious Potentials of Oyster Shell Powder for EcoFriendly and Low-Cost Concrete. Electronic Journal of Geotechnical Engineering 24 (5): 1297-1306.

Xianglin Gu Xianyu Jin, Yong Zhou, 2015. Basic Principles of Concrete Structures. Springer. 